SECTION 19. Management. Marketing. Public administration.

Mingazova Zulfiya Raisovna candidate of political Sciences,

The Bashkir state agrarian University

Russia, Republic of Bashkortostan, Ufa

\title{
INFLUENCE OF THE BUSINESS REPUTATION OF THE ETHNIC ASPECTS OF THE INSTITUTION OF THE STATE CIVIL SERVICE
}

The article examines the dominant influence on business reputation of civil servants.

Key words: ethnic aspects, goodwill.

\section{ВЛИЯНИЕ ДЕЛОВОЙ РЕПУТАЦИИ НА ЭТНИЧЕСКИЕ АСПЕКТЫ ИНСТИТУТА ГОСУДАРСТВЕННОЙ ГРАЖДАНСКОЙ СЛУЖБЫ}

В статье рассматриваются вопросы оказывающие доминирующее влияние на деловую репутаџию государственных гражданских служащих.

Ключевые слова: этнические аспекты, деловая репутачия.

$\begin{array}{rcrl}\text { Наряду } & \text { c } \text { позитивным } & \text { влиянием } & \text { внутрикорпорационного } \\ \text { направления } & \text { функционального } & \text { обеспечения } & \text { деловой репутации }\end{array}$ государственных гражданских служащих, как показывает конкретная практика и результаты многочисленных исследований, в нашей стране существенную, а иногда доминирующую роль играют семейнородственные и земляческие отношения как фактор осуществления государственной гражданской службы. Например, в исследованиях, проанализированных М.Н. Афанасьевым и отражающих ситуацию 1990-х годов, от 15 до $60 \%$ опрошенных фиксируют преобладающее значение семейно-родственных и земляческих связей при осуществлении кадровой политики в системе государственной службы [1, с. 227-228]. Итоги проведенных нами опросов также указывают на очень большое значение семейно-родственных и земляческих отношений. Причем мнение самих опрошенных нами госслужащих по этому вопросу значительно более пессимистичны. Так, 77,3 \% чиновников считают, что отношения клановости, землячества и этнократизма при подборе кадров не только существуют, но и доминируют, еще 7,6 \% считают, что такие факты имеются, хотя и не играют определяющей роли и только $15,2 \%$ ответили, что таких факторов практически не наблюдается, а подбор кадров осуществляется преимущественно по деловым и профессиональным 
качествам. Значительно в более мажорных тонах оценили влияние вышеперечисленных негативных факторов на современное состояние деловой репутации государственных гражданских служащих опрошенные нами студенты. Например, только четверть из них считает, что данное явление доминирует, а половина - подобные факты имеются, но они не преобладают.

В отдельных регионах РФ, при осуществлении кадровой политики, как показывают результаты некоторых политологических исследований, также происходило распространение элементов этнократизма, местничества, землячества и т.д. В этих условиях деловая репутация как фактор кадровой политики отходила на второй, а то и на третий план. Доминирующими становились не признаки профессионализма и управленческой квалификации, а принадлежности к определенной национальности, проживания на конкретной местности, родства и т.д. [2, с. 303-311]. По нашему мнению, деловая репутация как фактор кадровой политики может в полной степени быть реализована только в случае нейтрализации этнических, земляческих и клановых способов подбора и расстановки кадров в системе государственной гражданской службы. Результаты проведенных нами социологических опросов также подтверждают высказанную мысль. Так, 61,6 \% опрошенных госслужащих уверены в том, что элементы этнократизма, местничества, землячества в государственной кадровой политике играют отрицательную роль, т.к. определяющими становятся не признаки профессионализма и управленческой квалификации, а принадлежности к определенной национальности, проживания на конкретной местности, родства и т.д. Однако 30,8 \% позитивно настроены к подобным проявлениям кадровой политики, т.к., по их мнению, при управлении регионами необходимо представлять во власти проживающие здесь народы, клановые группировки, хорошо знать социокультурные особенности и традиции данной территории и т.п. Только 7,6 \% опрошенных затруднились ответить на данный вопрос. Приблизительно подобное распределение ответов получено и при опросе будущих госслужащих из числа студентов. Т.е. при общем отрицательном отношении к землячеству, местничеству и этнократизму, чиновники среднего уровня демонстрируют возрастающую толерантность к этим явлениям, обосновывая свою позицию необходимостью, при осуществлении кадровой политики, учета социокультурной специфики данной территории. Именно поэтому на вопрос о том, возможно ли в полной мере реализовать деловую репутацию как фактор кадровой политики при существовании этнических, земляческих и клановых способов подбора и расстановки кадров в системе государственной гражданской службы, более двух третей из числа опрошенных действующих и потенциальных чиновников ответили отрицательно, а около одной трети - сочли, что «данные способы особо не 
влияют на эффективность государственной гражданской службы».

Как показывают результаты проведенного нами сравнительного анализа, многие особенности использования деловой репутации в системе современной государственной гражданской службы в постсоветских государствах имеют «родимые пятна» советской системы государственного и местного управления. Например, в большинстве постсоветских государств специальное законодательство о государственной службе было принято довольно поздно, лишь к концу 1990-х г.г. При этом данное законодательство не имеет, во многих случаях, системного характера, отличается отрывочностью, не содержит специальных нормативных актов о государственной гражданской службе. Во многих случаях действующее законодательство страдает декларативностью и слабо регулирует реально существующие, но латентно функционирующие управленческие отношения. Например, как показывают специальные исследования, в т.ч. авторов из самих постсоветских государств, в течение постсоветского развития в бывших советских республиках Средней Азии и в Казахстане, а также в некоторых северо-кавказских республиках России, получили распространение отдельные проявления трайбализма. Так, как отмечает один из авторов, кадровая политика многих местных руководителей Казахстана диктуется племенными предпочтениями, как, например, в деятельности акима Жамбылской области А. Тшанова (1995-98). Слишком явные клановые противоречия привели даже к тому, что руководство республики оказалось вынужденно ликвидировать целую область - Тургайскую. Действия большей части казахской политической элиты, особенно в кадровой политике, подсознательно определяются принципом жузовой солидарности. Тем самым трайбализм, хотя и неофициально, играет значительную роль в обеспечении государственного управления в Казахстане [3]. Специальное и довольно глубокое исследование известного американского политолога Марты Брилл Олкотт показало даже, что традиции трайбализма, возродившиеся в постсоветском Казахстане, играют возрастающую роль не только на уровне среднего и нижнего уровней политической элиты, но и в процессе эволюции и взаимодействия своеобразного политического Олимпа - семьи Президента и близких к нему кланов и родов [4, с. 201-245]. Аналогичные явления, как показывают многочисленные исследования, получают широкое распространение не только в Казахстане, но и во всех республиках «советской» Средней Азии $[5$, c. $46-61 ; 6$, c. $128-139]$.

\section{Литература}

1. Афанасьев М.Н. Клиентелизм и российская государственность [Текст] / М.Н. Афанасьев. - М.: МОНФ, 1997. - 301 с. 
2. Регионы России. Хроника и руководители. Т. 8. Республика Марий Эл, Чувашская Республика, Республика Башкортостан [Текст] . - Sapporo: Slavic Research Center, Hokkaido University, 2003. - 342 c.

3. Гусев Л. Модернизирующийся трайбализм [Электронный ресурс]. URL: http://www.apn.kz/publications/article76.htm. (Дата доступа: 15.06.2013)

4. Олкотт Марта Брилл. Казахстан: непройденный путь [Текст] / М.Б. Олкотт. - М.: Гендальф, 2003. - 354 с.

5. Масанов Н.Э. Казахская политическая интеллектуальная элита: клановая принадлежность и внутриэтническое соперничество [Текст] / Н.Э. Масанов // Вестник Евразии. - 1996. - № 1 с. 46-6.

6. Амеркулов Н. Жузы в социально-политической жизни Казахстана [Текст] / Н. Амеркулов // Центральная Азия и Кавказ. - 2000. - № 3. - С. 128-139. 